\title{
Pengembangan Model Simulasi Kebijakan Pengelolaan Ikan Berkelanjutan
}

\author{
Ratna Purwaningsih ${ }^{1,2^{*}}$, Sjarief Widjaja ${ }^{1}$, Sri Gunani Partiwi ${ }^{3}$
}

\begin{abstract}
Stock assessment studies of Sardinella Lemuru Bali strait indicate overfishing. The growth of fishing vessel numbers result on fish biomass stock reduction. Sustainable fishery management in overfishing area can be done by limiting number of fishing effort. There are three kinds of methods approach on determine number of fishing effort and total allowed catch Maximum Sustainable Yield (MSY), Maximum Economic Yield (MEY) and Maximum Social Yield (MScY). Sustainable fishery has three main aspect as its indicators; ecology, economic and social. This research attempts to simulate three kinds of methods to the indicators of sustainable fishery, biomass fish stock as ecological aspect, profit of purse seine fishing vessel as economical aspect and numbers of fishers involved in the business of marine capture fishery represents social aspect. System dynamic method and powersim software are used in simulation model. Simulation output shows that fish biomass stock can be maintain in sustainable level by applied fishery policy. Limiting number of fishing effort create balancing between fish stock natural growth and fish harvest. This policy starts to apply on year 2010 in simulation model and run until 2030 to forecast future condition of fish biomass stock.
\end{abstract}

Keywords: Overfishing, limiting fishing effort, sustainable fishery, system dynamic simulation.

\section{Pendahuluan}

Perikanan tangkap (marine capture fisheries) memiliki peran penting karena ikan yang dihasilkan menjadi sumber protein bagi gizi masyarakat dan sektor ini menyediakan lapangan kerja bagi jutaan nelayan (DFID [5]). Usaha memaksimalkan hasil tangkap atau peningkatan produksi perikanan laut sering berujung pada pengelolaan perikanan yang tidak berkelanjutan sehingga terjadi kerusakan ekologi dan kerugian ekonomi.

Muncar adalah pelabuhan perikanan pantai (coastal fisheries port) di Propinsi Jawa Timur dengan area penangkapan (fishing area) perairan selat Bali dan produksi utama ikan Lemuru (Sardinella Lemuru). Melimpahnya hasil ikan Lemuru maka di sekitar pelabuhan Muncar tumbuh industri pengolahan yang menghasilkan ikan kaleng (Sardine, Tuna), tepung dan minyak ikan serta ikan beku (frozen fish). Tumbuhnya industri-industri ini meningkatkan tekanan terhadap upaya penang

1 Fakultas Teknologi Kelautan, Jurusan Teknik Perkapalan, Institut Teknologi Sepuluh Nopember Surabaya. Kampus Keputih Sukolilo, Surabaya 60111, Indonesia.

Email: ratna_ti2005@yahoo.com, sjarief.widjaja@yahoo.co.uk

${ }^{2}$ Fakultas Teknik, Program Studi Teknik Industri, Universitas Diponegoro. Jl. Prof. Dr. Soedharto, SH, Semarang 50269, Indonesia.

${ }^{3}$ Fakultas Teknologi Industri, Jurusan Teknik Industri, Institut Teknologi Sepuluh Nopember Surabaya. Kampus Keputih Sukolilo Surabaya, 60111, Indonesia.

Email: srigunani@ie.its.ac.id

* Penulis korespondensi kapan ikan Lemuru. Hal ini dapat dibuktikan dengan pertumbuhan jumlah alat tangkap.

Jumlah nelayan tahun 2000 adalah 11.974 orang meningkat menjadi 13.330 orang pada tahun 2009 dengan rata-rata peningkatan $1,32 \%$ per tahun. Jumlah alat penangkapan ikan meningkat dari 1.680 unit pada tahun 2000 menjadi 2.124 unit pada 2009 dengan rata-rata peningkatan 3,93\% per tahun (BPPI Muncar [3,4]). Alat tangkap untuk ikan Lemuru adalah pukat cincin (purse seine), payang dan bagan. Produksi terbesar Lemuru diperoleh dari pukat cincin. Jumlah kapal purse seine ini terus meningkat sejak dioperasikan pada 1975 (Buchary et al. [1]). Pada 1990, Dinas Kelautan dan Perikanan (DKP) Jatim dan DKP Bali membuat peraturan tentang pembatasan jumlah kapal purse seine yang beroperasi di Selat Bali karena berbagai kajian stok ikan Lemuru telah mengindikasikan terjadinya lebih tangkap (DKP Jatim [6]). Sampai tahun 2010 jumlah kapal purse seine tetap terjaga pada tingkat tersebut. Namun ukuran muatan kapal (GT/Gross tonnase), daya mesin dan jumlah ABK (anak buah kapal) sebenarnya terus meningkat (Setyohadi [17]).

Lebih tangkap atau overfishing diartikan sebagai jumlah ikan yang ditangkap melebihi jumlah yang diperbolehkan untuk mempertahankan stok ikan lestari dalam suatu wilayah laut tertentu. Salah satu penyebab kondisi di atas adalah adanya tekanan terhadap eksploitasi perikanan laut (fishing pressure). Dua hal yang diakui sebagai tekanan terhadap eksploitasi perikanan adalah pertumbuhan 
populasi dunia dan target pembangunan untuk mencapai pendapatan yang tinggi dari sektor perikanan. Kondisi ini diperburuk dengan sifat kepemilikan sumber daya perikanan sebagai common property, lemahnya pengawasan akan pembatasan kapal ikan dan illegal fishing (Fauzi [8]).

Widodo dan Suadi [20] menyatakan overexploited mengakibatkan waktu melaut menjadi lebih panjang, lokasi penangkapan lebih jauh, produktivitas (hasil tangkap per satuan upaya atau Catch per unit effort (CPUE) menurun, dan biaya penangkapan yang menjadi besar sehingga menyebabkan menurunnya keuntungan nelayan. Hal-hal di atas adalah indikasi terjadinya overfishing. Pembatasan jumlah kapal purse seine memang harus dilakukan untuk menjaga kelestarian perikanan Lemuru selat Bali dan agar tetap memberi keuntungan yang cukup bagi nelayan.

FAO dalam review terakhirnya mengenai kondisi sumber daya perikanan global memperkirakan bahwa dari 523 jenis ikan dunia yang telah dilakukan stock assessment, $52 \%$ sudah mengalami fully eksploited, $17 \%$ overexploited dan hanya $3 \%$ saja yang underexploited (FAO [7]). Penelitian lainnya dari Boris Worm menyampaikan bahwa diproyeksikan ikan akan punah dari perairan bumi tahun 2048 (Lukito [13]). Terjadinya berbagai kerusakan lingkungan dan kelangkaan sumber daya alam dan energi akibat eksploitasi yang tidak terkendali memaksa setiap negara menerapkan kebijakan Pembangunan Berkelanjutan atau 'sustainable development' dalam pengelolaan sumber daya alam. Pembangunan berkelanjutan diartikan oleh WCED sebagai pembangunan untuk memenuhi kebutuhan generasi sekarang dengan tetap menjamin terpenuhinya kebutuhan generasi yang akan datang (WCED [19]).

Nixon [14] menyatakan bahwa pembangunan berkelanjutan di bidang perikanan sudah mendesak untuk segera diwujudkan karena kondisi perikanan dunia saat ini telah berada pada kondisi krisis. Krisis ini terjadi karena laju ekstraksi sumber daya ikan melebihi kemampuan regenerasinya sehingga terjadi perubahan ekosistem yang menyebabkan menurunnya kemampuan produksi di masa yang akan datang. Kapasitas yang berlebih akibat investasi yang intensif di bidang perikanan selama 100 tahun terakhir menjadi penyebab overfishing (Fauzi, [8]).

Dalam pengelolaan perikanan berkelanjutan terdapat tiga pendekatan pengelolaan yaitu MSY, MEY dan MScY (Widodo dan Suadi [20]). Pada pendekatan MSY (Maximum Sustainable Yield), jumlah tangkapan dibatasi pada level tertentu agar stok ikan dapat terjaga pada tingkat mampu lestari, dapat dikatakan aspek ekologi menjadi titik berat pendekatan ini. Sedangkan pendekatan MEY (Maximum Economic Yield) menentukan jumlah tangkapan yang memberikan keuntungan ekonomi tertinggi (economic rent) per trip penangkapan. Pendekatan MScY (Maximum Social Yield) menentukan jumlah tangkapan dengan memaksimumkan jumlah upaya penangkapan sampai batas yang tidak menyebabkan menurunnya biomass stock ikan. Upaya penangkapan atau fishing effort adalah perkalian antara jumlah armada (kapal ikan) dengan jumlah trip melaut. Semakin besar upaya penangkapan yang diperbolehkan, maka akan semakin banyak nelayan yang dapat diserap sebagai pekerja, sehingga mengurangi pengangguran. Tampak bahwa pendekatan ini mengedepankan aspek sosial sebagai tujuan utamanya.

Pengembangan model simulasi dalam penelitian ini bertujuan memberikan estimasi kondisi mendatang sampai tahun 2030 jika diterapkan batasan upaya penangkapan sesuai ketiga skenario pendekatan pengelolaan perikanan di atas. Indikator penilaian meliputi aspek ekologi, ekonomi dan sosial. Tiga pendekatan yang disimulasikan akan memberi gambaran kondisi yang berbeda pada ketiga indikator tersebut. Informasi ini diharapkan dapat menjadi bahan pertimbangan bagi penentu kebijakan pengelolaan perikanan dalam mengambil keputusan yang tepat.

\section{Metode Penelitian}

Pengelolaan sumberdaya perikanan pada mulanya didasarkan pada konsep hasil maksimum lestari (MSY). Konsep ini berangkat dari model pertumbuhan biologi ikan yang dikembangkan oleh Schaefer [16].

\section{Model Gordon Schaefer}

Stok ikan dipengaruhi oleh laju pertumbuhan stok dan jumlah tangkapan. Stok ikan mampu berkembang hingga tingkat biomassa maksimumnya, dengan laju pertumbuhan tergantung pada kelimpahan stok $\left(B_{t}\right)$. Laju pertumbuhan stok ikan atau natural growth adalah pertambahan jumlah stok karena terjadinya perkembangbiakan ikan maupun pertumbuhan masa tubuh. Bila $B_{t}$ lebih kecil dari ukuran kelimpahan stok maksimum yang sesuai dengan daya dukung lingkungan $(K)$, maka stok ikan akan cenderung meningkat. Pertumbuhan maksimum terjadi pada $B_{t}$ tertentu, setelah itu angka pertumbuhan menurun hingga mencapai $K$. Sedangkan hasil tangkapan semakin besar seiring meningkatnya jumlah effort dan kelimpahan stok. Pada jumlah effort tertentu hasil tangkap akan mendekati laju pertumbuhannya. Pada kondisi 
inilah terjadi kesetimbangan antara hasil tangkap dengan laju pertumbuhan.

Laju pertumbuhan alami stok ikan yang tidak dieksploitasi digambarkan oleh Schaefer [16] dengan persamaan:

$F_{(t)}=\frac{d B_{(t)}}{d t}=r \times B_{(t)} \times\left(1-B_{t}\right) / K$

dimana

$F_{(t)}$ : laju pertumbuhan alami stok ikan

$B_{t} \quad$ : biomass stock saat $t$

$r \quad$ : laju pertumbuhan intrinsik spesies ikan yang diteliti

$K \quad$ : koefisien daya dukung lingkungan

Bila dilaksanakan kegiatan penangkapan, maka hasil tangkapan akan tergantung pada biomass stok saat ini, tingkat upaya penangkapan dan koefisien daya tangkap seperti digambarkan dengan persamaan:

$h_{(t)}=q \times E \times B_{(t)}$

$h_{(t)}:$ hasil tangkapan pada saat $t$

$q \quad$ : koefisien daya tangkap (dari suatu alat tangkap)

$E$ : tingkat upaya penangkapan (merupakan perkalian antara jumlah kapal dan trip melaut)

Pada kondisi kesetimbangan $F_{(t)}=h_{(t)}$ atau $\frac{d B_{(t)}}{d t}=0$ Hasil tangkap persatuan upaya (catch per unit effort CPUE) model MSY Schaefer dapat diestimasi dengan persamaan berikut:

$\frac{h}{E}=q K-\left(\frac{q^{2} K}{r}\right) E$

dimana $a=q K$ dan $b=q^{2} K / r$, sehingga tingkat upaya dan nilai maximum sustainable yield dari model Schaefer dapat ditentukan dengan persamaan:

$h_{M S Y}=a^{2} / 4 b=r K / 4$

$E_{M S Y}=a / 2 b=r / 2 q$

Namun demikian MSY hanya penggambaran suatu keseimbangan berdasarkan faktor biologi saja, padahal perikanan juga harus mempertimbangkan faktor ekonomi. Oleh karena itu, Gordon [11] kemudian menganalisis parameter ekonomi ke dalam model Schaefer untuk menghasilkan keseimbangan bio-ekonomi. Konsep ini dikenal dengan teori Gordon-Schaefer. Total perolehan dari usaha penangkapan $(T R)$ dituliskan dengan persamaan:

$T R=p \times h_{(t)}=p q E B_{t}$
Sedangkan total biaya penangkapan atau total cost (TC) dituliskan dengan persamaan:

$T C=c \times E$

$T R$ : total revenue atau total keuntungan per tahun

$p \quad$ : harga per satuan berat ikan

$c$ : biaya per upaya penangkapan

Penerimaan bersih sebagai keuntungan $\pi$ dari hasil tangkapan sebesar $h_{(t)}$ adalah:

$\pi=T R-T C=p \cdot h_{(t)}-c \cdot E=p \cdot q \cdot E B_{t}-c \cdot E$

Metode open access berupaya memaksimalkan effort. Effort ditentukan oleh jumlah armada kapal ikan dan rata-rata frekuensi melaut per tahun. Hasil tangkap kondisi open acces dihitung dengan persamaan berikut:

$h_{o A}=r c / p q[1-(c / p q K)]$

sedangkan tingkat upaya penangkapan pada kondisi open access diperoleh dari persamaan:

$E_{O A}=r / q[1-(c / p q K)]$

Tingkat penangkapan pada kondisi MEY diperoleh dengan persamaan:

$h_{M E Y}=\frac{r}{2 q}\left[1-\frac{c}{p q K}\right]$

Demikianlah cara menentukan jumlah tangkapan dan besarnya upaya penangkapan pada pendekatan MSY, MEY dan MscY. Selanjutnya dikembangkan model sistem dinamik untuk melakukan simulasi pengelolaan perikanan pada ketiga skenario pendekatan tersebut.

\section{Pengembangan Model dengan Sistem Dinamik}

Pemodelan dengan sistem dinamik menurut Forester [9] mensyaratkan adanya hubungan atau dependensi antar variabel sistem dan bahwa perubahan nilai variabel adalah merupakan fungsi waktu. Sub sistem stok ikan terkait dengan upaya penangkapan karena tingkat mortalitas ikan sebanding dengan jumlah tangkapan jika kematian alami diabaikan. Jumlah tangkapan ditentukan oleh besarnya upaya penangkapan (effort) dan jumlah stok ikan. Pertumbuhan stok ikan melibatkan variabel-variabel seperti pada persamaan (1). Untuk menentukan besarnya upaya penangkapan pada alat tangkap yang beragam (multigears), maka berbagai alat tangkap tersebut dikonversikan ke dalam standar alat tangkap yang dominan (memberi jumlah tangkapan terbanyak per unit alat tangkap berdasarkan data historis). 
Terdapat tiga kelompok nelayan yang melakukan penangkapan Lemuru di perairan selat Bali, yaitu nelayan Bali (Pengambengan), nelayan Muncar dan nelayan di pesisir Banyuwangi yang tidak mendaratkan hasil tangkapannya di Muncar. Ketiga kelompok ini harus dilibatkan dalam model karena pengelolaan perikanan harus bersifat holistik. Seluruh upaya penangkapan yang beroperasi pada wilayah tersebut akan memberi pengaruh pada stok ikan Lemuru dan kelestariannya. Gambar 1 menjelaskan causal loop diagram dari model sistem dinamik perikanan Lemuru selat Bali.

Pengembangan formulasi model sebagian besar didasarkan pada persamaan-persamaan matematis yang sudah dikenal luas sehingga validasi output tidak dilakukan dan lebih mengutamakan pada validasi struktur (Ullah [12]). Selain itu, tingginya angka illegal and unreported fishing di perairan Indonesia menyebabkan penelitian perikanan sulit melakukan validasi output untuk data jumlah tangkapan atau total catch (Sedik [18], Buchary [2]).

Pengumpulan data didasarkan pada data sekunder dari berbagai sumber baik instansi pemerintah (DKP Jatim, DKP Bali, BPPI Muncar) dan penelitian sebelumnya tentang kajian stok perikanan Lemuru selat Bali. Data ekonomi untuk menentukan biaya per trip dan biaya investasi kapal diperoleh dari wawancara dengan nelayan dan pemilik kapal di Muncar antara 2010 - 2011.

Indikator perikanan yang digunakan adalah indikator utama dari dimensi perikanan berkelanjutan, yaitu stok biomassa, total tangkapan Lemuru, dan effort atau upaya penangkapan. Keuntungan per tahun per kapal (dengan asumsi harga ikan konstan) menjadi indikator aspek ekonomi.

\section{Sub Sistem Stok Ikan Sardinella Lemuru}

Metode estimasi stok ikan yang dipakai dalam penelitian ini yaitu metode tradisional dengan pendekatan model surplus produksi karena dalam penelitian ini stok ikan adalah satu kesatuan biomassa seluruh ikan, baik ikan yang masih kecil maupun yang sudah dewasa, dan tidak memperhitungkan strukturnya (ukuran ikan, umur ikan, dan jenis kelamin). Nilai awal yang diinputkan dalam model serta stock and flow diagram stok ikan Lemuru disajikan pada Gambar 2.

Nilai stok biomassa $t_{0}$ (tahun 2000) diinputkan sebesar 155.995 ton, $r=0,86$ per tahun, $K$ diduga sebesar 252.484,3 ton/tahun. Nilai $r, K$ dan $B_{t_{0}}$ didasarkan pada penelitian Setyohadi [17].

Perairan selat Bali bersifat multi spesies maka hasil perikanan dipilah atas ikan Lemuru (target species)

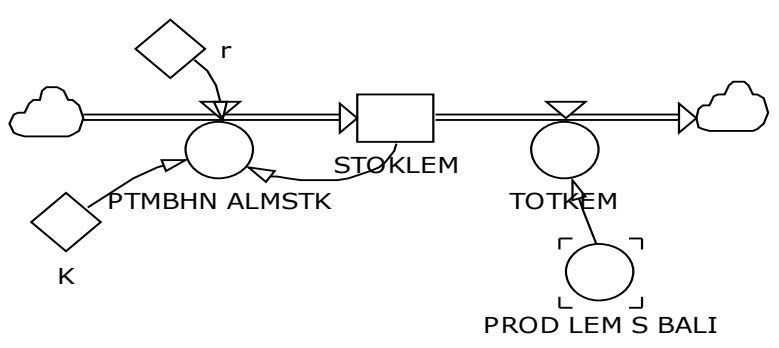

Gambar 2. Stock dan flow diagram sub sistem stok ikan

Tabel 1. Produksi perikanan Lemuru di PPP Muncar tahun $2000-2009$

\begin{tabular}{crcccc}
\hline Tahun & $\begin{array}{c}\text { Produksi } \\
\text { Lemuru (kg) }\end{array}$ & $\%$ & $\begin{array}{c}\text { Produksi } \\
\text { by catch }(\mathrm{kg})\end{array}$ & $\%$ & $\begin{array}{c}\text { Total } \\
\text { produksi }\end{array}$ \\
\hline 2000 & 4.101 .574 & 35 & 7.577 .174 & 65 & 11.678 .748 \\
2001 & 6.781 .206 & 45 & 8.286 .854 & 55 & 15.068 .060 \\
2002 & 15.831 .075 & 68 & 7.319 .468 & 32 & 23.150 .543 \\
2003 & 25.618 .960 & 75 & 8.439 .881 & 25 & 34.058 .841 \\
2004 & 15.933 .526 & 67 & 7.844 .013 & 33 & 23.777 .539 \\
2005 & 9.020 .670 & 78 & 2.545 .206 & 22 & 11.565 .876 \\
2006 & 51.336 .512 & 87 & 7.478 .773 & 13 & 58.815 .285 \\
2007 & 54.089 .139 & 90 & 6.304 .509 & 10 & 60.393 .648 \\
2008 & 27.833 .004 & 78 & 7.923 .632 & 22 & 35.756 .636 \\
2009 & 28.446 .134 & 87 & 4.336 .863 & 13 & 32.782 .997 \\
\hline
\end{tabular}

dan ikan lainnya (by catch). Produksi by catch ini dibangkitkan sesuai dengan model distribusinya yaitu distribusi normal dengan nilai rata-rata 6.990 ton dan standar deviasi 1.790 ton. Produksi non Lemuru Muncar antara tahun 2000-2009 disajikan dalam Tabel 1.

Proporsi jumlah tangkapan atas by catch ini antara purse seine dan non purse seine didasarkan pada data historis antara tahun 2000-2009. Purse seine mendapat $60 \%$ dari produksi non Lemuru Muncar setiap tahunnya.

\section{Sub Sistem Upaya Penangkapan}

Simulasi dilaksanakan dengan empat skenario, yaitu kondisi tanpa pengelolaan dimana kebijakan pembatasan jumlah kapal tidak terlaksana dengan baik (sebagai existing condition), pendekatan MSY, pendekatan MEY dan pendekatan Open Access (OA) atau MScY.

Pada skenario tanpa regulasi, alat tangkap mengalami pertumbuhan dengan tingkat tertentu setiap tahunnya. Pertumbuhan jumlah alat tangkap menjadikan dinamika pada jumlah tangkapan menurut fungsi waktu. Jumlah tangkapan ditentukan oleh nilai stok ikan dan effort (jumlah alat tangkap $\mathrm{x}$ frekuensi melaut). Simulasi pada tiga skenario lainnya dilakukan dengan mengunci nilai effort atau upaya penangkapan sesuai nilai yang diperoleh dari perhitungan matematis.

Beberapa nilai input lainnya untuk simulasi sub sistem upaya penangkapan diantaranya: 


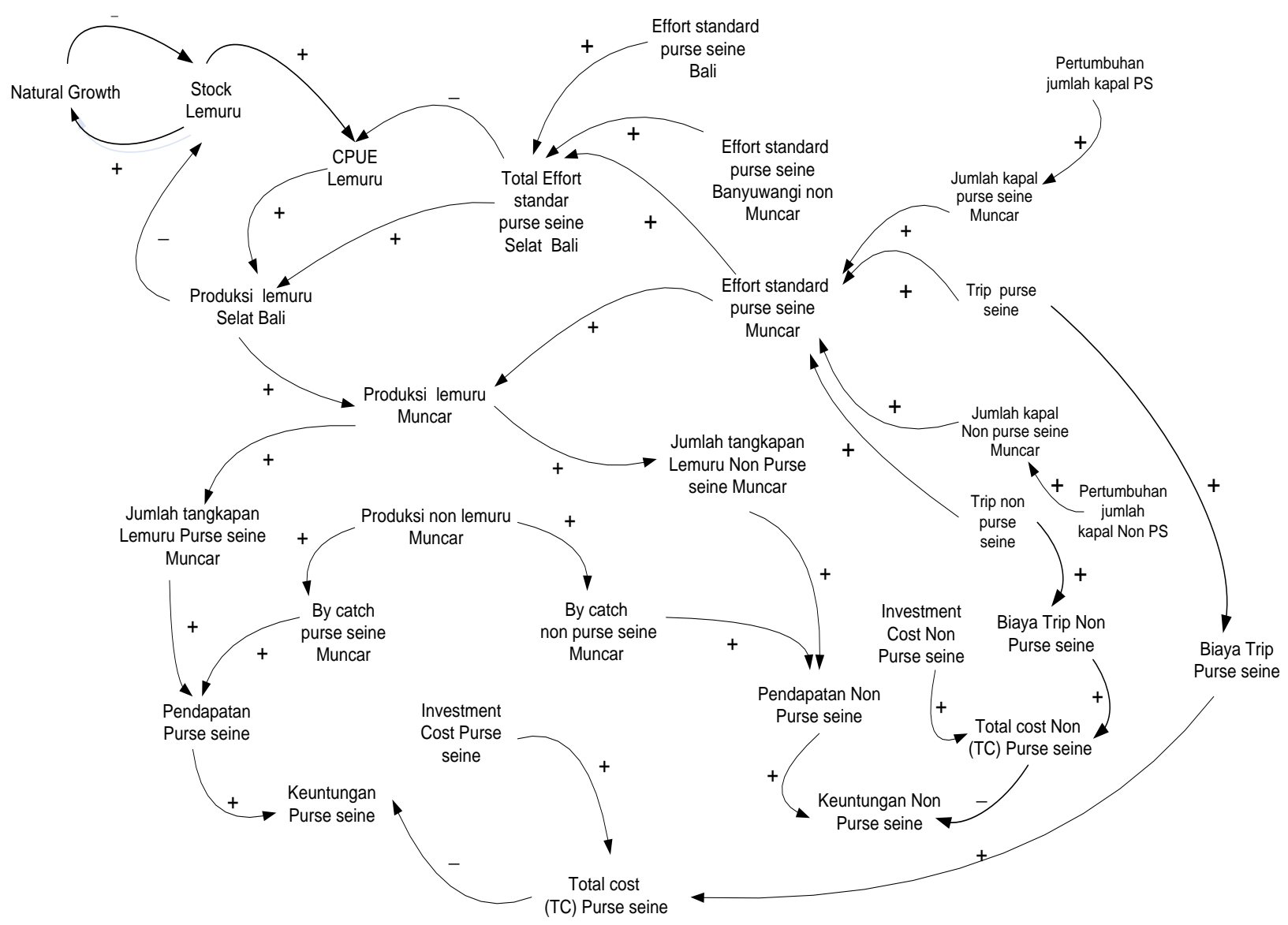

Gambar 1. Causal loop diagram

Jumlah kapal Purse seine pada tahun $2000\left(t_{0}\right): 180$ unit. Trip/tahun purse seine: 126 trip/tahun. CPUE non purse seine dikonversi ke standar purse seine: 0,089. Jumlah kapal non purse seine pada tahun $2000\left(t_{0}\right): 337$ unit. Trip/tahun non purse seine: 33 trip/tahun. $q$ (coefficient of technology) $=0,000018$.

Terdapat dua matode bagi kapal purse seine dalam menangkap Lemuru, yaitu dengan satu kapal atau one boat system dan cara "tandem" atau two boat system dengan mengoperasikan dua kapal secara bersama. Satu kapal sebagai pemburu dan satu kapal untuk memuat beban. Dalam simulasi ini teknik penangkapan ikan diabaikan. Kedua teknik penangkapan tersebut tentu memberikan nilai CPUE yang berbeda namun tidak tersedia data spesifik yang dibutuhkan sebagai input simulasi.

Keragaman alat tangkap (multigears) dikonversikan ke standar purse seine berdasarkan nilai CPUE yang mencerminkan perbandingan perolehan jumlah tangkapan per trip per kapal antara berbagai alat tangkap dibandingkan dengan purse seine. Jadi jika nilai CPUE 0,01 berarti jumlah tangkapan 1 unit alat tangkap tersebut per trip adalah 1/100 dibandingkan dengan hasil tangkapan 1 unit purse seine per trip. Nilai CPUE dihitung dengan menggunakan data historis jumlah kapal, trip, dan jumlah tangkapan.
Pengembangan model pengelolaan perikanan harus bersifat holistik, maka seluruh armada yang mengeksploitasi perairan laut selat Bali dilibatkan dalam model. Terdapat tiga macam kelompok nelayan yang beroperasi di perairan selat Bali, yaitu nelayan kecamatan Muncar kabupaten Banyuwangi, nelayan sepanjang pesisir Banyuwangi di luar Muncar dan nelayan Pengambengan kabupaten Jembrana, Bali. Armada kapal ikan dari ketiga kelompok ini dilibatkan dalam pengembangan model, namun dalam hasil dan pembahasan hanya difokuskan pada wilayah Muncar.

Tabel 2. Trip standar purse seine selat Bali

\begin{tabular}{|c|c|c|c|c|c|}
\hline \multirow{4}{*}{ Tahun } & \multicolumn{5}{|c|}{ Trip pada Standar Purse Seine } \\
\hline & Total & & Total & Banyuwangi & \\
\hline & Selat & Bali & Banyu- & (selain & Muncar \\
\hline & Bali & & wangi & Muncar) & \\
\hline 2000 & 28.739 & 9.784 & 18.955 & 13.290 & 5.665 \\
\hline 2001 & 22.225 & 10.082 & 12.143 & 5.536 & 6.607 \\
\hline 2002 & 15.192 & 7.138 & 8.054 & 2.995 & 5.059 \\
\hline 2003 & 18.151 & 9.183 & 8.968 & 4.376 & 4.592 \\
\hline 2004 & 33.069 & 12.390 & 21.219 & 3.755 & 17.464 \\
\hline 2005 & 42.103 & 13.794 & 28.309 & 2.388 & 25.921 \\
\hline 2006 & 38.236 & 13.769 & 24.467 & 1.427 & 23.040 \\
\hline 2007 & 36.476 & 11.036 & 25.440 & 1.976 & 23.464 \\
\hline Rerata & & 10.897 & & 4.468 & \\
\hline
\end{tabular}

Sumber: Setyohadi, 2010, diolah dari data BPPI Muncar, DKP Kab Jembrana dan DKP Kab Banyuwangi 
Tabel 3. JTB dan trip optimal pada berbagai pendekatan pengelolaan perikanan

\begin{tabular}{lccc}
\hline Pendekatan JTB (ton/thn) & Effort & $\begin{array}{c}\text { Jumlah PS pada } \\
\text { trip 126 }\end{array}$ \\
\hline MSY & 54.360 & 23.921 & 190 unit \\
MEY & 48.370 & 16.004 & 127 unit \\
OA & 48.012 & 42.103 & 334 unit \\
\hline
\end{tabular}

\section{Hasil dan Pembahasan}

Muncar adalah pelabuhan ikan terbesar di wilayah tersebut dengan status pelabuhan perikanan pantai (coastal fishery port). Pada 2009 terdapat 13.330 nelayan dan setiap unit kapal purse seine rata-rata berisi 43 orang, maka pada rata-rata 126 trip melaut per tahun jumlah purse seine pada pendekatan MSY

sekitar 190 unit. Saat ini pembatasan jumlah kapal yang ditetapkan oleh DKP Prop Bali dan DKP Prop Jatim hanya berlaku pada purse seine. Alat tangkap non purse sebenarnya juga menyumbang sekitar 20 $\%$ dari total tangkapan. Sebagai gambaran, Tabel 2 menyajikan data trip melaut standar purse seine di perairan selat Bali antara 2000-2007.

Besarnya trip melaut sangat menentukan produksi perikanan. Trip melaut memiliki rentang data yang lebar yang menunjukkan variabilitas yang tinggi. Trip melaut pada tahun 2004-2007 berbeda signifikan dengan tahun-tahun sebelumnya.

Nelayan menaikkan trip melaut dengan ekstrim pada saat terjadi El Nino (Ghofar [10]). Peristiwa alam ini menyebabkan up welling sehingga lebih banyak plankton tersedia di permukaan laut. Ikan Lemuru adalah jenis ikan yang hidup di permukaan laut (pelagis) dan hidup dalam kelompok (school) sehingga pada waktu terjadi El Nino terjadi peningkatan stok ikan yang cukup tinggi. Tentu saja hal ini juga mendongkrak produksi perikanan Lemuru.

Pada 2009 sebanyak 34 ribu ton ikan didaratkan di PPP Muncar, 28 ribu ton adalah ikan Lemuru dan sekitar 4 ribu ton adalah by catch, terdiri dari ikan layang, teri, kembung, tongkol, tuna dll. Perikanan Lemuru setiap tahunnya menyumbang produksi pelabuhan Muncar antara 30\%-90\%. Rata-rata produksi Lemuru berdasarkan data antara tahun $2000 \mathrm{~s} / \mathrm{d}$ tahun 2009 adalah $23.899 .180 \mathrm{~kg}$ dan ikan jenis lain sebesar 6.805.637 kg. Rata-rata prosentase produksi Lemuru terhadap total produksi PPP Muncar adalah 71\% (lihat Tabel 1).

\section{Hasil Simulasi Kebijakan Pengelolaan Perikanan}

Simulasi dengan software Powersim akan dijalankan dari tahun 2010-2030. Simulasi pendekatan MSY, MEY dan MScY baru dijalankan untuk tahun
2010, sedangkan antara tahun 2000-2009 menggunakan input data riil. Hasil penghitungan matematis untuk ketiga pendekatan tersebut dirangkum pada Tabel 3. Nilai-nilai effort ini diinputkan sebagai nilai effort mulai tahun 2010 bagi pendekatan pengelolaan perikanan MSY, MEY dan MScY, dengan mengunci effort pada nilai tersebut diharapkan output simulasi jumlah tangkapan akan memberikan hasil seperti jumlah tangkapan yang diperbolehkan (JTB) seperti yang direncanakan pada tabel setelah tercapainya steady state stok ikan. JTB ini diharapkan berimbang dengan laju pertumbuhan stok ikan sehingga tercipta keseimbangan antara eksploitasi dan laju produksi seperti yang disyaratkan pada pengelolaan perikanan berkelanjutan.

Hasil simulasi disajikan dalam grafik-grafik pada Gambar 3 sampai Gambar 6. Gambar-gambar tersebut menunjukkan perbandingan antara kondisi regulasi pembatasan jumlah tangkapan (JTB) tidak dipatuhi dibandingkan dengan jika dilakukan pembatasan JTB dengan pendekatan MSY, MEY dan MScY.

\section{Pengelolaan Perikanan tanpa Pembatasan Upaya Penangkapan}

Stok ikan pada kondisi skenario tanpa JTB berada pada kondisi deplesi karena upaya penangkapan terus bertambah seiring pertumbuhan jumlah kapal. Pertumbuhan purse seine ditetapkan sebesar 0,9\%/tahun dan non purse seine sebesar 4,5\%/thn.

\section{Kondisi Stok Lemuru Selat Bali}

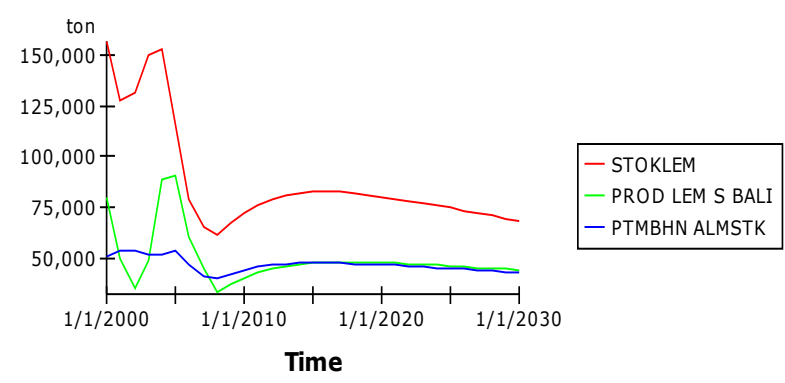

Gambar 3.a. Stok ikan Lemuru pada pengelolaan tanpa JTB

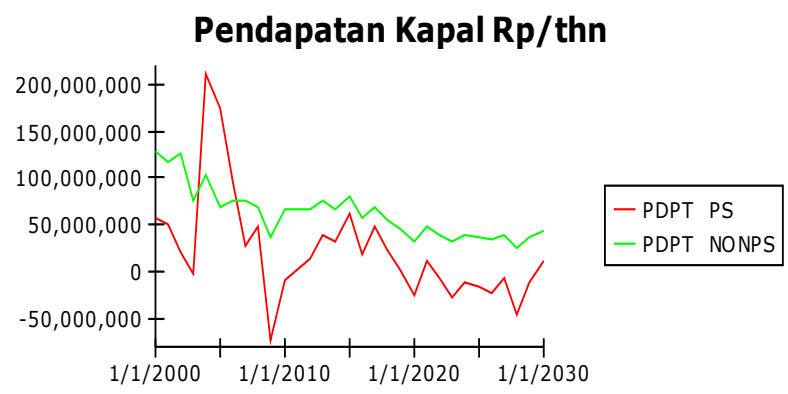

Gambar 3.b. Keuntungan nelayan pada pengelolaan tanpa JTB 
Terjadi kerugian yang besar pada alat tangkap purse seine terutama pada 2009, dan setelah tahun 2020 purse seine semakin merugi.

Fluktuasi keuntungan yang terjadi lebih disebabkan oleh by catch atau tangkapan non Lemuru yang relatif stabil sepanjang tahun. Pada 2015 diperoleh by catch sebesar 23.799 ton dan pada 2030 sebesar 24.374 ton. Keuntungan kapal non purse seine pada kondisi stok ikan yang deplesi lebih baik karena biaya trip melaut maupun biaya investasi untuk kapal non purse seine cukup murah.

\section{Pengelolaan Perikanan dengan Pendekatan MSY}

Pada pendekatan MSY hubungan antara effort dengan jumlah tangkapan diperoleh dengan memasukkan nilai pertumbuhan intrinsik $(r)$, daya dukung lingkungan Lemuru Selat Bali $(K)$, dan koefisien catch ability $(q)$, ke persamaan (6), maka diperoleh persamaan $h(t)=4,545 \mathrm{E}-0,000095 \mathrm{E}^{2}$. Hasil perhitungan matematis dengan persamaan tersebut memberikan nilai effort maksimum lestari (f $f_{\text {MSY) }}$ per tahun sebesar 23.921 trip pada standar purse seine dan hasil tangkapan maksimum lestari (MSY) perikanan Lemuru sebesar 54.360 ton per tahun.

Diberlakukannya pembatasan effort menyebabkab terjadinya peningkatan stok ikan. Kondisi steady state dari stok tercapai pada tahun 2021 yaitu sebesar 126.000 ton.

Terjaganya biomass stock ikan ini membawa dampak pada keuntungan kapal purse seine dan non purse seine. Sejak 2010 kapal tidak pernah mengalami kerugian. Fluktuasi keuntungan adalah hasil dari fluktuasi by catch, produksi by catch pada 2030 adalah 24.373 ton. Pada 2030 keuntungan purse seine sebesar Rp 245.555.119 dan non purse seine sebesar Rp 118.943.717.

\section{Pengelolaan Perikanan dengan Pendekatan MEY}

Hasil analisis MEY menunjukkan bahwa optimum produksi 48.370 ton/tahun dan dibutuhkan effort fMEY sebesar 16.004 trip/tahun. Hasil ini diperoleh dengan harga Lemuru Rp 4000,00/kg, harga ikan by catch $\mathrm{Rp} 7000$ dan biaya melaut sebesar $\mathrm{Rp}$ 3.750.000/trip (Purwaningsih [15]). Biaya investasi telah dibagi rata sesuai umur pakai (life time) kapal dan mesin kapal menjadi biaya tetap per tahun (annual fix cost) sebesar Rp 166.530.000. Keuntungan adalah pengurangan revenue atau pendapatan dari penjualan ikan hasil tangkapan dengan biaya terdiri dari biaya melaut (trip cost) dan biaya tetap tahunan.

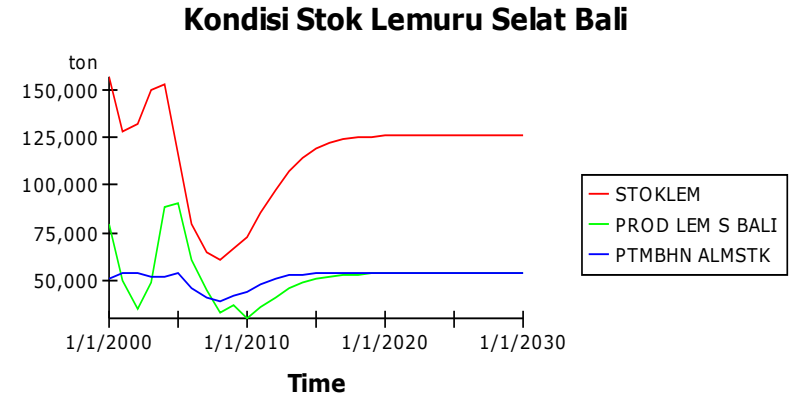

Gambar 4.a. Stok ikan Lemuru pada JTB pendekatan MSY

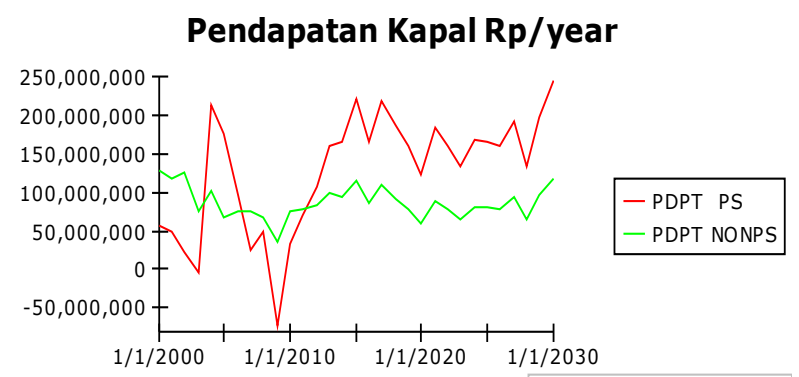

Gambar 4.b. Keuntungan nelayan pada JTB pendekatan MSY

\section{Kondisi Stok Lemuru Selat Bali}

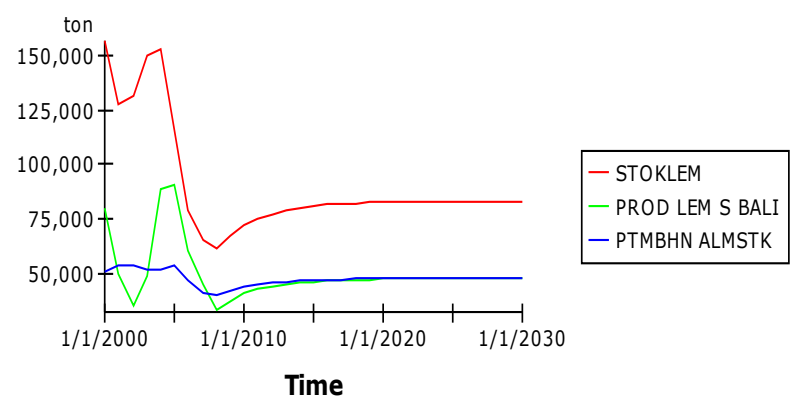

Gambar 6.a. Stok ikan Lemuru pada JTB pendekatan OA

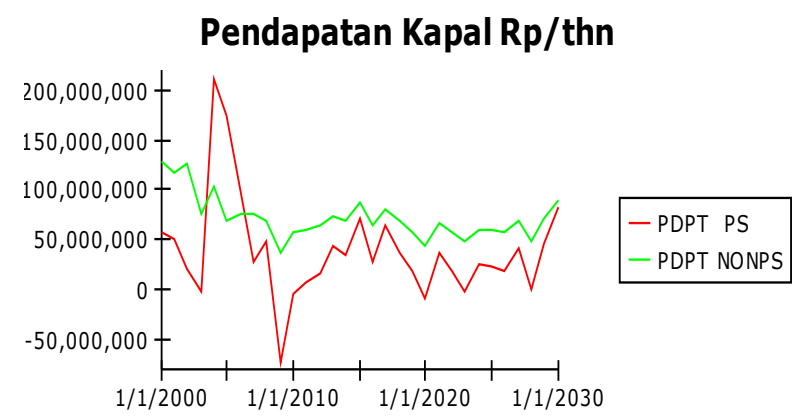

Gambar 6.b. Keuntungan nelayan pada JTB pendekatan $\mathrm{OA}$

Pada pendekatan MEY fluktuasi keuntungan lebih disebabkan oleh by catch (produksi non Lemuru). Tampak bahwa sejak 2010 ketika diberlakukan pembatasan effort, terjadi kenaikan stok ikan secara signifikan. Kondisi steady state stok tercapai pada 2018 sebesar 167.000 ton. 
Keuntungan kapal dengan pendekatan MEY adalah yang tertinggi dibanding skenario lainnya. Pada 2030 purse seine mendapat keuntungan sebesar Rp 461.702.152 dan non purse seine sebesar $\mathrm{Rp}$ 176.374.521. Pendapatan kapal dengan pendekatan ini hampir dua kali lipat dibanding pada pendekatan MSY.

\section{Pengelolaan Perikanan dengan Pendekatan MScY}

Effort pada titik MScY produksi ikan Lemuru selat Bali sebesar 33.009 trip dengan hasil tangkap optimum 48.012 ton. Perhitungan ini menggunakan asumsi-asumsi biaya yang sama dengan yang digunakan pada perhitungan MEY.

Hasil tersebut menunjukkan bahwa effort yang semakin besar ternyata memberikan hasil yang lebih sedikit jika dibandingkan hasil tangkap pada titik MEY. Pada open access sumberdaya ikan diekstraksi sampai pada titik yang terendah, berarti usaha tidak didasarkan pada efisiensi ekonomi. Apabila usaha penangkapan masih tetap dilanjutkan melampaui MScY maka stok ikan Lemuru akan collapse. Steady state stok ikan hasil simulasi tercapai pada 2020 yaitu sebesar 83.000 ton.

Pendapatan kapal berada disekitar garis batas karena pendekatan ini seperti Break Even Point atau titik impas pada usaha perikanan. Pada 2030 pendapatan purse seine sebesar Rp 41.871 .317 dan non purse seine sebesar $\mathrm{Rp}$ 69.028.448. Pendapatan non purse seine lebih baik karena biaya operasional dan investasi yang lebih rendah.

\section{Menentukan Kebijakan Pengelolaan Terbaik}

Berbagai kebijakan Pengelolaan perikanan yang disimulasikan memiliki titik berat tujuan yang berbeda untuk dicapai. Penetapan JTB dan effort dengan pendekatan Maximum Sustainable Yield menekankan pada aspek ekologi, Maximum Economic Yield pada memaksimalkan keuntungan ekonomi dari upaya penangkapan dan Maximum Sosial Yield mengutamakan aspek sosial dengan memaksimalkan effort atau jumlah tenaga kerja yang terserap. Rangkuman hasil simulasi sebagai perbandingan dari berbagai kebijakan pengelolaan disajikan dalam Tabel 4.

Berdasarkan Tabel 4 dapat diketahui bahwa output simulasi pada kondisi steady state telah memberikan hasil yang tidak jauh berbeda dengan hasil perhitungan formulasi matematis baik untuk stok ikan maupun estimasi jumlah tangkapan sesuai jumlah effort yang diinputkan untuk masing-masing jenis pendekatan pengelolaan (MSY, MEY dan OA).
Pada kondisi steady state system dari model yang dikembangkan juga telah tercapai sebuah kondisi equilibrium atau keseimbangan antara laju pertumbuhan alami stok ikan/thn dengan jumlah tangkapan/tahun atau $F_{(t)}=h_{(t)}$. Hal ini berarti struktur model yang disusun dengan menerapkan formulasi matematis tersebut cukup valid menurut validasi struktur (structural validation) karena formulasi yang dibangun telah sesuai dengan behaviour atau perilaku model. Validasi output sulit dilaksanakan mengingat tingginya tingkat illegal fishing dan unreported fishing di berbagai pelabuhan perikanan Indonesia. Buchary [2] dalam penelitiannya menyebutkan nilai unreported fishing antara 40\%-60\%.

Penggunaan simulasi untuk menguji penerapan kebijakan dengan memprediksi nilai berbagai indikator yang diamati pada masa yang akan datang sangat berguna bagi para pengambil keputusan. Pendekatan matematis memang dapat menetapkan jumlah effort optimal dan batasan jumlah tangkapan untuk sebuah pengelolaan perikanan berkelanjutan, namun tidak dapat memprediksi kapan kondisi kesetimbangan atau sustainable tersebut dapat dicapai. Pendekatan matematis juga tidak dapat memperkirakan seberapa besar recovery atau pertambahan stok ikan setelah kebijakan pembatasan jumlah tangkapan diterapkan.

Pengelolaan perikanan Lemuru yang berkelanjutan memiliki peran strategis karena banyak industri yang tergantung pada hasil produksi Lemuru. Menurut data dari pemerintah kabupaten Banyuwangi 2010, terdapat 43 industri cold storage, 9 pabrik pengalengan ikan sardine, 35 unit industri tepung dan minyak ikan serta 86 unit industri pengolahan ikan tradisional. Pada 2009, keseluruhan industri tersebut menyerap 5.811 orang tenaga kerja.

Indonesia adalah negara berkembang yang masih menghadapi masalah pengangguran dan pemerintah selalu menetapkan kebijakan "padat karya" dalam pengelolaan industri. Dinas Kelautan dan Perikanan Jawa Timur dan Bali sebagai pihak yang berwenang menetapkan kebijakan pengelolaan perikanan selat Bali menetapkan jumlah armada perikanan dengan memaksimalkan serapan tenaga kerja (pendekatan Open Access). Namun harus diingat bahwa kebijakan ini hanya menjamin stok ikan lestari pada tingkat yang paling rendah dan memberi keuntungan ekonomi terendah dibanding kebijakan lainnya.

Alternatif penyelesaian masalah pengangguran nelayan karena menetapkan batasan jumlah kapal yang beroperasi adalah dengan mengkaji pergeseran fishing ground nelayan ke wilayah perairan laut yang masih under exploited seperti laut selatan 
Tabel 4. Perbandingan output hasil simulasi

\begin{tabular}{|c|c|c|c|c|c|c|}
\hline No & Indikator & Satuan & $\begin{array}{l}\text { Skenario } 1 \\
\text { Tanpa JTB }\end{array}$ & $\begin{array}{c}\text { Skenario } 2 \\
\text { MSY }\end{array}$ & $\begin{array}{c}\text { Skenario } 3 \\
\text { MEY }\end{array}$ & $\begin{array}{c}\text { Skenario } 4 \\
\text { OA }\end{array}$ \\
\hline 1 & Indikator Perikanan (ekologi) pada 2030 & & & & & \\
\hline 1.1 & Biomass stock lemuru $B_{(t)}$ & Ton/ thn & 68.443 & 126.235 & 167.914 & 83.335 \\
\hline 1.2 & Jumlah tangkapan $h_{(t)}$ ton & Ton/thn & 44.321 & 54.283 & 48.369 & 48.008 \\
\hline 1.3 & Laju pertumbuhan $F_{(t)}$ ton & Ton/thn & 42.905 & 54.284 & 48.369 & 48.013 \\
\hline 2. & Indikator ekonomi pada 2030 & & & & & \\
\hline 2.1 & Keuntungan purse seine & $\mathrm{Rp} / \mathrm{thn}$ & 10.783 .428 & 245.555 .119 & 461.702 .152 & 41.871.317 \\
\hline 2.2 & Keuntungan non purse seine & $\mathrm{Rp} / \mathrm{thn}$ & 42.356.147 & 118.943.717 & 176.374.521 & 69.028 .448 \\
\hline & CPUE purse seine & Ton/trip & 1,232 & 2,272 & 3,022 & 1,500 \\
\hline 3. & Indikator sosial pada 2030 & & & & & \\
\hline 3.1 & Pendapatan ABK P. Seine & $\mathrm{Rp} / \mathrm{thn}$ & 9.263 .102 & 14.722 & 19.749 .584 & 10.906 \\
\hline 3.2 & Effort standar purse seine* & Trip/thn & 20.611 & 11.418 & 7.648 & 15.294 \\
\hline 3.3 & Jumlah nelayan terserap ${ }^{* *}$ & Orang/thn & 7009 & 3870 & 2580 & 5203 \\
\hline 4. & Indikator model & & & & & \\
\hline 4.1 & Steady state stok ikan tercapai pada tahun & tahun & & 2021 & 2018 & 2020 \\
\hline 4.2 & Nilai $B_{(t)}$ steady state & Ton/thn & deplesi & 126.000 & 167.000 & 83.000 \\
\hline
\end{tabular}

* Hanya effort di Muncar, belum termasuk di Pengambengan Bali dan pesisir Banyuwangi diluar Muncar

**Jika diasumsikan 1 kapal purse seine membutuhkan 43 ABK dan trip melaut 126 trip/thn

Jawa (Samudra Indonesia). Selain itu perlu pula dikaji alternatif pengembangan marikultur atau perikanan budidaya untuk menjaga ketersediaan ikan bagi konsumsi masyarakat dan bahan baku industri.

\section{Simpulan}

Beberapa kesimpulan yang dapat diambil sebagai hasil dari simulasi kebijakan pengelolaan perikanan Lemuru selat Bali diantaranya adalah bahwa tanpa menerapkan kebijakan pembatasan jumlah alat tangkap maka akan terjadi deplesi pada stok ikan Lemuru perairan selat Bali yang berakibat kerugian bagi usaha perikanan tangkap purse seine.

Pembatasan jumlah upaya penangkapan (effort) dengan pendekatan MSY, MEY dan OA jika mulai diterapkan sejak tahun 2010 akan mampu menjaga kelestarian stok ikan Lemuru dan keberlanjutan ekonomi bagi usaha perikanan tangkap purse seine Muncar Banyuwangi dengan keuntungan yang memadai bagi pemilik kapal.

Kondisi kesetimbangan atau equilibrium telah tercapai dimana nilai laju pertumbuhan stok ikan atau biomass stock natural growth ikan sebanding dengan nilai jumlah tangkapan atau harvest sehingga tercipta pengelolaan perikanan yang berkelanjutan (sustainable fishery) dalam model simulasi.

\section{Daftar Pustaka}

1. Buchary, E., Pitcher, T. J., and Ganapathiraju P., An Estimation of Compliance of the Fisheries of Indonesia with Article 7, Fisheries Management of the UN Code of Conduct for Responsible Fishing, 2008.
2. Buchary, E., In Search of Viable Policy Option for Responsible Use of Sardine Resources in the Bali Strait of Indonesia, Ph D Thesis, University of British Columbia, 2010.

3. BPPI Muncar, Laporan Tahunan 2009.

4. BPPI Muncar, Laporan Tahunan 2010.

5. DFW, A Framework for Linking Poverty to Policy in the Post-Harvest Fisheries Sector, DFID's PostHarvest Fisheries Research Programe, 2004.

6. DKP Jatim, Perikanan Lemuru Selat Bali, Proceeding of FAO Fishcode Management, Papers Presented at the Workshop on the Fishery and Managementof Bali Sardinella (Sardinella Lemuru) in Bali Strait, Rome, June 2000.

7. FAO, Fisheries and Aquaculture Development, The State of World Fisheries and Aquaculture, Rome, 2008.

8. Fauzi, A., Kebijakan Perikanan dan Kelautan, Isu, Sintesis, dan Gagasan, Gramedia Pustaka Utama, Jakarta, 2005.

9. Forrester, J. W., Industrial Dynamics, the M.I.T. Press, New York, 1961.

10. Ghofar, A, Mathew, C. P., Merta, I. G. S., and Salim, S., Incorporating the Southern Oscillation Indices to the Management Model of the Bali Strait Sardinella Lemuru, papers presented at the Workshop on the Fishery and Management of Bali Sardinella (Sardinella Lemuru) in Bali strait, FAO proceeding, 2000.

11. Gordon, R. M., The Optimal Management of Transboundary Renewable Resources, Canadian Journal of Economic, 12(3),pp. 355-376, August 1979.

12. Ullah, H. Q., Structural Validation of System Dynamic and Agent Based Simulation Model, Proceeding of $19^{\text {th }}$ European Commission for Modelling and Simulation, 2005.

13. Lukito, O., Optimalisasi Subsektor Perikanan dalam Menopang Pembangunan Nasional dan 
Daerah, Proceeding Seminar Nasional Perikanan Universitas Brawijaya, Malang, 2007.

14. Nixon, A., World Fisheries, the Current Crisis, Lybrary of Parliament, France, 1997.

15. Purwaningsih, R., and Hidayat, F., Pengembangan Model Simulasi Pengaruh Kenaikan Bahan Bakar Minyak terhadap Keuntungan Nelayan (Studi Kasus Nelayan Purse Seine Muncar, Banyuwangi), Proceeding Seminar Nasional Teknik Industri XV (SNTI XV), Surabaya, 2011.

16. Schaefer, B., and Martin, A., Study of the Dynamic of the Fishery of Yellowfin Yuna in the Eastern Tropical Pasific Ocean, Inter-America Tropical Tuna Commission Buletin, II(6), California, 1957.
17. Setyohadi, D., Kajian Pemanfaatan Sumberdaya Ikan Lemuru (Sardinella Lemuru) di Selat Bali: Analisis Simulasi Kebijakan Pengelolaan 2008-2020, Disertasi, Universitas Brawijaya, Malang, 2010.

18. Sodik, D. M., Combatting, Ilegal, Unreported and Unregulated Fishing in Indonesian Waters: The Need for Fisheries Legislatif Reform, Thesis, University of Wollongong, Australia, 2007.

19. WCED, World Commission on Environment and Development, Our Common Future, Report of the World Commission on Environment and Development, 1987.

20. Widodo, J., and Suadi, Pengelolaan Sumberdaya Perikanan Laut, Gadjah Mada University Press, Yogyakarta, 2006. 